\title{
The effect of accelerated aging on the color stability and translucency of novel zirconia reinforced rice husk dental composite resin in different infusion media
}

O efeito do envelhecimento acelerado na estabilidade de cor e translucidez de uma nova resina composta de casca de arroz reforçada com zircônia em diferentes meios de infusão

Galvin Sim Siang LIN $^{1}$ (), Nik Rozainah Nik Abdul GHANI ${ }^{1}$ (), Noor Huda ISMAIL ${ }^{2}$ (), Tahir Yusuf NOORANI ${ }^{1}$ (1)

1 - Universiti Sains Malaysia, School of Dental Sciences, Conservative Dentistry Unit. Kubang Kerian, Kelantan, Malaysia.

2 - Universiti Sains Malaysia, School of Dental Sciences, Prosthodontics Unit. Kubang Kerian, Kelantan, Malaysia.

\begin{abstract}
Objective: To compare the color stability and translucency of aged and unaged experimental zirconia reinforced rice husk nanohybrid composite resin (Zr-Hybrid) with a commercialized nanofilled and a microhybrid composite resin after immersion in four different infusion media. Material and Methods: Three groups of standardized disc-shaped composite resin with 80 samples per group were prepared as follow: Group 1 (Filtek-Z350-XT), Group 2 (Zmack-Comp), and Group 3 (Zr-Hybrid). Each group was further subdivided into aged $(\mathrm{n}=40)$ and unaged $(n=40)$ groups. Initial color measurements were taken using a digital spectrophotometer based on CIE $\mathrm{L} * \mathrm{a}$ * ${ }^{*}$ color system. Samples in aged subgroup were subjected to 2500 thermal cycles. Subsequently, all samples were immersed in four different types of infusion media $(n=10): T_{1}$ - Distilled water, $T_{2}-$ Soft drink, $T_{3}-$ Tea and $\mathrm{T}_{4}$ - Coffee. After 15 days, color measurements of all samples were measured again. Data were analyzed using two-way ANOVA followed by Bonferroni and paired sample t-tests with a significance level set at $P=0.05$. Results: Unaged Zr-Hybrid showed comparable color change to Zmack-Comp and Filtek-Z350-XT ( $P=0.181$ ), but aged $\mathrm{Zr}$-Hybrid demonstrated the lowest color change $(P<0.001)$. Zr-Hybrid exhibited the lowest translucency value $(P<0.001)$, but no significant color and translucency changes ( $P=0.051$ and $P=0.069$, respectively) were observed between unaged and aged Zr-Hybrid. Soft drink had the greatest effect $(P<0.001)$ on color change, while coffee showed the greatest effect $(P<0.001)$ on translucency. Conclusion: Although Zr-Hybrid showed greater opacity, it still retained its color stability and translucency after accelerated aging compared to commercialized microhybrid and nanofilled composite resins. All infusion media caused discoloration and affected the composite resins' translucency.
\end{abstract}

\section{KEYWORDS}

Rice husk; Color stability; Composite resin; Translucency; Zirconia.

\section{RESUMO}

Objetivo: Comparar a estabilidade de cor e translucidez de uma resina composta nanohíbrida de casca de arroz reforçada com zircônia experimental envelhecida e não envelhecida (Zr-Hybrid) com uma resina composta comercial nanoparticulada e microhíbrida após a imersão em quatro meios de infusão diferentes. Material e Métodos: Três grupos de resina composta em forma de disco padronizado com 80 amostras por grupo foram preparados da seguinte forma: Grupo 1 (Filtek-Z350-XT), Grupo 2 (Zmack-Comp) e Grupo 3 (Zr-Hybrid). Cada grupo foi subdividido em grupos de envelhecimento $(n=40)$ e não envelhecimento $(n=40)$. As medições iniciais de cor foram feitas usando um espectrofotômetro digital baseado no sistema de cores CIE $L$ * a * $b$ *. As amostras do subgrupo envelhecido foram submetidas a 2500 ciclos térmicos. Posteriormente, todas as amostras foram imersas em quatro tipos diferentes de meios de infusão $(n=10)$ : T1 - Água destilada, T2 - Refrigerante, 
T3 - Chá e T4 - Café. Após 15 dias, as medições de cor de todas as amostras foram medidas novamente. Os dados foram analisados usando ANOVA dois fatores seguido por Bonferroni e testes t pareados com nível de significância estabelecido em $\mathrm{P}=0,05$. Resultados: $\mathrm{O}$ grupo $\mathrm{Zr}$-Hybrid não envelhecido mostrou uma mudança de cor comparável a Zmack-Comp e Filtek-Z350-XT ( $\mathrm{P}=0,181)$, mas o grupo Zr-Hybrid envelhecido demonstrou a menor mudança de cor $(\mathrm{P}<0,001)$. Zr-Hybrid exibiu o menor valor de translucidez $(\mathrm{P}<0,001)$, mas nenhuma mudança significativa de cor e translucidez $(\mathrm{P}=0,051 \mathrm{e} \mathrm{P}=0,069$, respectivamente) foram observadas entre Zr-Hybrid não envelhecido e envelhecido. $O$ refrigerante teve o maior efeito $(P<0,001)$ na mudança de cor, enquanto o café apresentou o maior efeito $(\mathrm{P}<0,001)$ na translucidez. Conclusão: Apesar do grupo Zr-Hybrid tenha mostrado maior opacidade, ele ainda manteve sua estabilidade de cor e translucidez após envelhecimento acelerado em comparação com resinas compostas micro-híbridas e nanoparticuladas comercializadas. Todos os meios de infusão causaram descoloração e afetaram a translucidez das resinas compostas.

\section{PALAVRAS-CHAVE}

Casca de arroz; Estabilidade de cor; Resina composta; Translucidez; Zircônia.

\section{INTRODUCTION}

C omposite resins have become one of the most widely used dental restorative materials for decades. With advances in nanotechnology, nanocomposites have been developed and introduced [1]. The benefits of these new nanocomposites include better mechanical properties, improved fracture resistance, outstanding polish performance, minimal shrinkage, and optimal color stability $[1,2]$. Dental materials such as dental composite resins are continuously exposed to the oral environment and are susceptible to changes in their physical, mechanical, and optical properties. Undeniably, discoloration of dental composite resin is considered one of the greatest challenges faced by clinicians $[3,4]$. Discoloration is by far one of the most common causes of replacement for composite resin restoration, especially in anterior teeth $[3,5]$. Since the esthetic value of a composite resin restoration is dependent on the ability to maintain its color and harmonize with natural teeth, therefore, the key element is to address the color stability and translucency [6-8].

Color difference $(\Delta \mathrm{E})$ is commonly used to determine the changes in the color shade that are perceivable and acceptable to the human observer [9]. There are two systems in use to assess color differences, which are the Munsell Color System and Commission International de l'Eclairage (CIE) Color System. The latter is extensively used by many researchers [4,9-11]. According to CIE, the color parameters ( $\mathrm{L}^{*}, \mathrm{a}^{*}$, $\mathrm{b}^{*}$ ) of test material can be measured by means of a reflectance or transmittance spectrum dependent on a standard illuminate and precise geometry [12]. In addition to color stability, translucency is a paramount consideration for the esthetic component of composite resin restoration. One of the most acceptable methods to measure composite resin's translucency is the translucency parameter (TP), which is defined as the color variations of composite resin with a standardized thickness over white and black backgrounds [11].

With the current global environmental issue, silica extracted from environmental assets has begun to attract interest as an alternative for filler reinforcement in dental materials [13]. Silica derived from rice husk has recently been introduced as filler in polymer composite due to several advantages such as low cost, ease of availability and environment friendliness [14]. Even so, there is still relatively little information in the literature on the use of rice husk silica as filler in a dental composite resin $[15,16]$. Although the physical and mechanical properties of conventional and zirconia reinforced rice husk nanohybrid composite resin have been reported to be slightly inferior, these values are still within a reasonable range and comparable to those of the commercially available microhybrid composite resin, Z 250 [15,17].

To the best of the authors' knowledge, no study on the optical properties of novel zirconia reinforced rice husk dental composite resin has been published. Thus, the present study aimed to compare the color stability and translucency of aged and unaged new experimental zirconia reinforced rice husk nanohybrid composite resin (Zr-Hybrid) with commercially available nanofilled and microhybrid composite resins after being immersed in four different infusion media. The first null hypothesis was that there is no significant difference in the color stability 
and translucency of the experimental Zr-Hybrid when compared with commercially available nanofilled and microhybrid composite resins after being immersed in different infusion media. The second null hypothesis tested was that there is no significant difference in terms of optical properties when comparing the aged and unaged experimental composite resin after immersion in different infusion media.

\section{MATERIAL AND METHODS}

As described in previous studies [18,19], 50 wt.\% of Bis-phenol A-glycidyl methacrylate (Bis-GMA) was added with 48 wt. $\%$ of Triethylene-glycol-dimethacrylate (TEGDMA), 1 wt.\% camphorquinone (CQ) and 1 wt.\% of dimethylaminoethyl methacrylate (DMAEMA) to form the resin matrix. The filler particles composed of $60 \mathrm{wt} . \%$ of nano-silica obtained from rice husk produced from the Universiti Sains Malaysia using sol-gel method. The resin matrix and rice husk silica filler were then mixed with the addition of $10 \mathrm{wt} . \%$ zirconia nanopowder (MFCD00011310, American Elements, Los Angeles, US). A homogenous material was formed with the resin to filler ratio of 70:30. The final experimental nanohybrid composite resin was then kept in the refrigerator at $4{ }^{\circ} \mathrm{C}$ for further use.

The three different composite resins were grouped as follow:

Group 1: Nanofilled (Filtek-Z350-XT, 3M ESPE, St Paul, USA)

Group 2: Microfilled (Zmack-Comp, Zhermack, Badia Polesine, Italy)

Group 3: Experimental nanohybrid (Zr-Hybrid, Universiti Sains Malaysia, Kelantan, Malaysia)
The compositions and manufacturer descriptions of each type of composite resin are summarized in Table I.

Standardized round disc (diameter $10 \mathrm{~mm}$; height $2 \mathrm{~mm}$ ) with 80 samples in each composite resin group were prepared by inserting the material into the mold. To achieve a smooth and flat surface, waterproof clear plastic stretch films (Manual Stretch Film, Scientex, Shah Alam, Malaysia) were placed on top and bottom of the samples and pressed manually between two glass slides (GLP2X2, United Scientific Supplies, Inc., Waukegan, US). The composite resin samples were polymerized using an $800 \mathrm{~mW} / \mathrm{cm}^{2}$ intensity light-curing device (Elipar Free Light 2, 3M ESPE, St. Paul, MN, USA). By positioning a 1-mm-thick glass slide (GLP2X2, Unified Science Supplies, Inc., Waukegan, US) between the light curing device and the sample, the irradiation distance was standardized. During the polymerization process, the light-curing tip was ensured to be in contact with the glass slide.

To ensure that the output of the light source was standardized throughout the experiment, the light-curing device was calibrated by a light-emitting diode radiometer (Demetron, Kerr, Danbury, CT, USA) before the start of the experiment and after every two samples. The polymerization process was conducted for 40 seconds as recommended by the manufacturers. Subsequently, glass slides and plastic films were gently removed. For each composite resin group, the 80-disc-samples were subdivided into two subgroups of 40 samples each (aged and unaged). The two sub-groups were further divided into 10 samples each according to the type of infusion media (Figure 1) as follows.

A pH meter (CYBERSCAN 510, Eutech, Landsmeer, Netherlands) was used to measure the $\mathrm{pH}$ of each infusion media. The $\mathrm{pH}$ values of

Table I - Compositions of composite resins used in this study

\begin{tabular}{|c|c|c|c|c|}
\hline Type of Composite Resin Used & Shade & Resin Monomer & Filler (wt.\%, vol.\%) & $\begin{array}{l}\text { Filler size range } \\
(\mu \mathrm{m})\end{array}$ \\
\hline Nanofilled (Filtek-Z350-XT, 3M ESPE) & \multirow{3}{*}{ A3 } & $\begin{array}{l}\text { Bis-GMA, Bis-EMA, UDMA, } \\
\text { TEGDMA, PEGDMA }\end{array}$ & Zirconia \& silica $(78.5,63.3)$ & $0.004-0.02$ \\
\hline Microhybrid (Zmack-Comp, Zhermack) & & Bis-GMA, Bis-EMA, TEGDMA & $\begin{array}{l}\text { Barium glass \& silicon } \\
\text { dioxide }(77,57)\end{array}$ & $0.04-1.5$ \\
\hline $\begin{array}{l}\text { Experimental Nanohybrid (Zr-Hybrid, } \\
\text { Universiti Sains Malaysia) }\end{array}$ & & Bis-GMA, TEGDMA & $\begin{array}{l}\text { Zirconia \& rice husk silica } \\
(70,48.3)\end{array}$ & $0.03-0.53$ \\
\hline
\end{tabular}

Bis-GMA = Bis-phenol A-glycidyl methacrylate; Bis-EMA = Ethoxylated Bisphenol-A-Dimethacrylate; TEGDMA = Tri-ethylene-glycoldimethacrylate; UDMA = Urethane dimethacrylate; PEGDMA = polyethylene glycol dimethacrylate. 


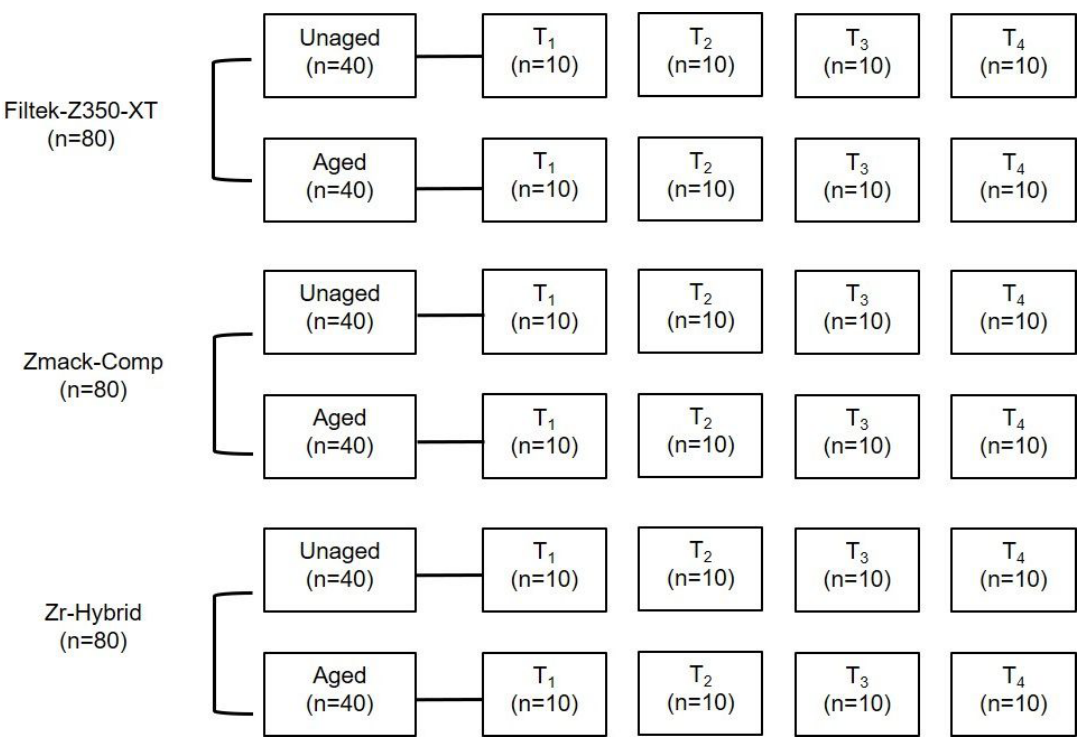

Figure 1 - Distribution of study groups. ( $T_{1}=$ distilled water; $T_{2}=$ soft drinks; $T_{3}=T$ Tea; $T_{4}=$ coffee). $T_{1}=$ Distilled water $\left(\right.$ control); $T_{2}=$ Soft drink (Pepsi Black, PepsiCo, Kuala Lumpur, Malaysia); $\mathrm{T}_{3}=$ Tea (Oolong tea, Chamomile 'BOH' tea, BOH Plantations Sdn Bhd, Pahang, Malaysia); $\mathrm{T}_{4}=$ Coffee (NESCAFE 3-in-1 original, Nestlé, Kuala Lumpur, Malaysia).

distilled water, soft drink, tea, and coffee were noted to be $6.5,3.2,6.8$ and 5.5 , respectively.

First, initial color measurements were performed and recorded as baseline readings using a digital spectrophotometer (VITA Easyshade ${ }^{\circledR}$ V, VITA Zahnfabrik, Bad Säckingen, Germany) for all composite resin samples. The measurements were made with the spectrometer tip (active point) positioned at the middle part of the composite resin samples. The samples were stored in their respective infusion media according to their groups. All solutions used were placed at room temperature. The tea and coffee solutions were prepared by adding a packet of soluble tea and coffee powders into $250 \mathrm{ml}$ of water at $40^{\circ} \mathrm{C}$ according to each manufacturer's instructions, followed by adequate stirring and being left undisturbed to cool down to room temperature before the composite resin samples were immersed. The infusion media were placed in $250 \mathrm{ml}$ beakers (PYREX® Griffin Low-Form Beakers, Thomas Scientific, Thomas Scientific, US) containing $150 \mathrm{ml}$ of each infusion media.

The unaged composite resin samples of each experimental group were placed in respective beakers for 15 days as per previous similar studies [20,21]. Infusion media were replaced every 3 days to prevent microbial growth. The aged subgroup composite resin samples were placed in thermal cycling machine (TS Series Liquid, Weiss Technik, North America) and subjected to 2500 thermal cycles of $5{ }^{\circ} \mathrm{C}, 37^{\circ} \mathrm{C}$ and $55^{\circ} \mathrm{C}$ sequential water baths with 30 seconds dwell time and 5 seconds transfer time. Subsequently, they were placed in respective beakers containing infusion media as described for unaged groups. After 15 days, color measurements were performed again using the same digital spectrophotometer. The color change measurement was set to 'Restoration mode' in which shade A3 was selected. The thresholds for composite resin perceptibility and clinical acceptability were set at $\Delta \mathrm{E}=1.30$ unit and $\Delta \mathrm{E}=3.30$ unit, respectively [10].

All measurements were collected three times to determine the mean values. The color measurement was based on the CIE L*a*b* color space method. $L^{*}$ represented value (lightness or darkness), a* represented the measure of redness (positive $\mathrm{a}^{*}$ ) or greenness (negative $\left.a^{*}\right)$, whereas $b^{*}$ represented the measure of yellowness (positive $b^{*}$ ) or blueness (negative $\left.b^{*}\right) .^{8,11}$ The values of $L^{*} a^{*} b^{*}$ were referred as the differences in the color parameters of composite resins between the initial measurements and the measurements taken after 15 days of immersion in infusion media in relation to the pre-set value (shade A3). The color values were measured with a standard white background (CIE L* $=81.9$, $a^{*}=19.8$, and $b^{*}=20.4$ ) placed behind the composite resin samples to reduce background color effect on the measurement values. The color difference $(\Delta \mathrm{E})$ was calculated as follow [8]:

$\Delta \mathrm{E}^{*}=\left[\left(\Delta \mathrm{L}^{*}\right)^{2}+\left(\Delta \mathrm{a}^{*}\right)^{2}+\left(\Delta \mathrm{b}^{*}\right)^{2}\right]^{1 / 2}$

The same samples from color stability test were used to measure the translucency. 
Translucency parameter (TP) was calculated by determining the color difference of $L^{*} a * b *$ on both white and black backgrounds:

$\left.\mathrm{TP}=)^{2}\right]^{1 / 2}$

whereby $L_{W}^{*}, a_{W}^{*}$ and $b_{W}^{*}$ were measured over white background of $\mathrm{L}^{*}=81.9, \mathrm{a}^{*}=19.8$, and $\mathrm{b}^{*}=20.4$, and $L_{B}^{*}, a_{B}^{*}$ and $b_{B}^{*}$ were measured over black background of $L^{*}=8.6, a^{*}=-0.7$, and $b^{*}=-1.5$.

A high TP value indicates the composite resin sample is more translucent, while a low TP value indicates that the composite resin sample is more opaque.

Statistical analysis was performed using SPSS version 24.0 (IBM, Corp, Armonk, NY). ShapiroWilk's test confirmed a normally distributed value. Color change and translucency values were analyzed using two-way ANOVA and Post hoc Bonferroni test for multiple comparisons between composite resin groups and different infusion media, respectively. Paired sample t-test was applied to compare the color change and translucency between aged and unaged composite resin materials in the four different infusion media. The significance level was set at $P=0.05$.

\section{RESULTS}

Table II shows the results of color change $(\Delta \mathrm{E})$ among all three composite resins after immersion in different infusion media. No significant difference $(P=0.181)$ in the color change was found among all unaged composite resins, but a significant color change $(P=0.001)$ was noted among aged composite resins after being immersed in all fourinfusion media. In general, soft drink had the most significant impact on color change $(P<0.05)$ followed by coffee, tea, and lastly distilled water in both unaged and aged subgroups. However, no significant difference $(P=0.051)$ was noted between aged and unaged Zr-Hybrid immersed in soft drink, tea, and coffee, respectively.

Table III shows the results of translucency parameter (TP) among all three composite

Table II - Mean ( \pm standard deviation) of the color changes $(\triangle E)$ of different composite resins immersed in four types of infusion media with and without accelerated aging

\begin{tabular}{|c|c|c|c|c|c|}
\hline \multirow{2}{*}{ Group } & \multicolumn{4}{|c|}{ Type of Infusion Media } & \multirow{2}{*}{$P$-value } \\
\hline & $\mathrm{T}_{1}$ & $\mathrm{~T}_{2}$ & $\mathrm{~T}_{3}$ & $\mathrm{~T}_{4}$ & \\
\hline \multicolumn{6}{|l|}{ Unaged } \\
\hline Filtek-Z350-XT & $2.05( \pm 0.21)^{a}$ & $5.83( \pm 0.34)^{b}$ & $4.97( \pm 0.11)^{c}$ & $5.09( \pm 0.47)^{d}$ & \multirow{3}{*}{0.181} \\
\hline Zmack-Comp & $2.10( \pm 0.28)^{a}$ & $5.92( \pm 0.41)^{b}$ & $5.06( \pm 0.31)^{c}$ & $5.15( \pm 0.38)^{d}$ & \\
\hline Zr-Hybrid & $2.06( \pm 0.23)^{a}$ & $5.89( \pm 0.46)^{b} x$ & $5.00( \pm 0.41)_{Y}^{c}$ & $5.12( \pm 0.38)_{z}^{d}$ & \\
\hline \multicolumn{6}{|l|}{ Aged } \\
\hline Filtek-Z350-XT & $3.21( \pm 0.26)^{e}$ & $8.87( \pm 0.44)^{f}$ & $7.47( \pm 0.29)^{\mathrm{g}}$ & $7.09( \pm 0.37)$ & \multirow{3}{*}{$0.001^{*}$} \\
\hline Zmack-Comp & $3.14( \pm 0.31)^{e}$ & $8.82( \pm 0.35)^{f}$ & $7.26( \pm 0.40)^{g}$ & $6.36( \pm 0.40)$ & \\
\hline Zr-Hybrid & $2.75( \pm 0.51)$ & $5.91( \pm 0.33)_{x}$ & $5.08( \pm 0.24)_{Y}$ & $5.13( \pm 0.45)_{z}$ & \\
\hline
\end{tabular}

$T_{1}=$ distilled water; $T_{2}=$ soft drinks; $T_{3}=$ Tea; $T_{4}=$ coffee. Significant at $P=0.05^{\star}$. Same superscript lowercase letters within column indicate no statistical difference (P>0.05); same subscript capital letters within column indicate no statistical difference (P>0.05).

Table III - Mean ( \pm standard deviation) of the translucency parameters (TP) of different composite resins immersed in four types of infusion media with and without accelerated aging

\begin{tabular}{|c|c|c|c|c|c|}
\hline \multirow{2}{*}{ Group } & \multicolumn{4}{|c|}{ Type of Infusion Media } & \multirow{2}{*}{$P$-value } \\
\hline & $\mathrm{T}_{1}$ & $\mathrm{~T}_{2}$ & $\mathrm{~T}_{3}$ & $\mathrm{~T}_{4}$ & \\
\hline \multicolumn{6}{|l|}{ Unaged } \\
\hline Filtek-Z350-XT & $18.46( \pm 0.32)^{a}$ & $14.99( \pm 0.41)^{b}$ & $12.30( \pm 0.46)^{c}$ & $10.65( \pm 0.45)^{d}$ & \multirow{3}{*}{$0.001^{\star}$} \\
\hline Zmack-Comp & $18.17( \pm 0.68)^{a}$ & $14.78( \pm 0.54)^{b}$ & $12.07( \pm 0.14)^{c}$ & $10.81( \pm 0.36)^{d}$ & \\
\hline $\mathrm{Zr}$-Hybrid & $13.31( \pm 0.24)_{w}$ & $10.87( \pm 0.34)^{b} x$ & $9.05( \pm 0.13)_{Y}^{c}$ & $7.52( \pm 0.24)^{d}{ }_{z}$ & \\
\hline \multicolumn{6}{|l|}{ Aged } \\
\hline Filtek-Z350-XT & $16.16( \pm 0.34)^{e}$ & $13.38( \pm 0.44)^{f}$ & $10.43( \pm 0.11)^{g}$ & $9.61( \pm 0.32)^{\mathrm{h}}$ & \multirow{3}{*}{$0.001^{\star}$} \\
\hline Zmack-Comp & $16.04( \pm 0.31)^{e}$ & $12.92( \pm 0.35)^{f}$ & $10.36( \pm 0.40)^{g}$ & $9.47( \pm 0.36)^{h}$ & \\
\hline Zr-Hybrid & $13.17( \pm 0.44)_{w}$ & $10.65( \pm 0.19)_{x}^{f}$ & $8.92( \pm 0.35)^{g}{ }_{Y}$ & $7.38( \pm 0.17)_{z}^{h}$ & \\
\hline
\end{tabular}

( $T_{1}=$ distilled water, $T_{2}=$ soft drinks, $T_{3}=T e a, T_{4}=$ coffee). Significant at $0.05^{*}$. Same superscript lowercase letters within column indicate no statistical difference (P>0.05); same subscript capital letters within column indicate no statistical difference (P>0.05). 
resins after being immersed in different infusion media. Zr-Hybrid was found to exhibit the lowest translucency value $(P<0.05)$ in all infusion media for both unaged and aged subgroups. Nonetheless, no significant difference in the translucency parameter $(P=0.069)$ was noted between aged and unaged Zr-hybrid. In relation to the type of infusion media, coffee had the most significant impact $(P<0.05)$ on the translucency of all composite resin materials followed by tea, soft drink, and lastly distilled water for both aged and unaged subgroups.

\section{DISCUSSION}

The first null hypothesis was partly denied according to the results in the present study. Previous studies suggested that color value of $\Delta \mathrm{E}<1.3$ is imperceptible to the human eye, while a value of $\Delta \mathrm{E}>3.3$ is considered as clinically undesirable [22-24]. However, the findings in our study revealed that all composite resin materials demonstrated clinically unacceptable $\Delta \mathrm{E}$ values except composite resins immersed in distilled water. Indeed, the highest $\Delta \mathrm{E}$ values among unaged and aged composite resins were noted in Zmack-Comp and Filtek-Z350-XT immersed in soft drink with values of $\Delta \mathrm{E}=5.92$ and $\Delta \mathrm{E}=8.87$, respectively. Zr-Hybrid showed no significant change in color after accelerated aging for all infusion media and this proved the excellent ability of Zr-Hybrid to maintain its color property in long term as compared to other commercialized composite resins. Thus, the second null hypothesis is accepted.

The infusion media used in this study were soft drink, tea and coffee which are among the most frequently consumed drinks [7,9]. When comparing different infusion media, distilled water was found to cause the least discoloration with clinically acceptable color differences $(\Delta \mathrm{E}<3.3)$ which is in line with other studies $[3,4,7,8]$. This suggested that water absorption alone will not induce drastic changes in the composite resin color to a considerable extent [25]. On the other hand, soft drink was found to cause the greatest degree of discoloration which could be due to the low $\mathrm{pH}$ of soft drink that might negatively affect the surface integrity, softening the resin matrix and causing ions to leach into the composite resin, thus, increasing the resin surface roughness and leading to more pigment staining [26].
The color stability of composite resins may be affected by numerous factors such as type of resin matrix used, size of filler particles, amount of filler content and the depth of light cure $[3,27]$. Studies have suggested that composite resin discoloration is related to the hydrophilic properties of the resin matrix used [3,5,7]. BisGMA which is present in all composite resins used in the present study exhibits high water affinity due to its hydroxyl groups, causing hydrolytic degradation of the polymeric chain and affecting the color stability of resin matrix by absorbing more coloring agent $[3,5,27,28]$. Urethane dimethacrylate (UDMA) based monomer which is only present in Filtek-Z350-XT according to the manufacturer, is reported to cause a lower color change as compared to other dimethacrylate based monomers due to its low viscosity and low water affinity $[5,9,29]$. Surprisingly, the results of this study seem to be contradicted as FiltekZ350-XT showed a higher value of discoloration than Zr-Hybrid after accelerated aging.

Besides, composite resins with a high concentration of TEGDMA in their composition tend to release a large amount of monomers in aqueous media as compared to Bis-GMA and UDMA, therefore, resulting in a higher degree of discoloration [28]. This, however, also contradicts with the findings of the present study as Zr-Hybrid with higher TEGDMA proportion in its resin matrix demonstrated the lowest color change after accelerated aging which is an interesting finding. This may be explained by their filler particle size.

Larger filler particles will increase the chance to expose the surface of composite resin which will produce higher surface roughness value and lead to a greater degree of discoloration [30]. This explained the overall high $\Delta \mathrm{E}$ value in Zmack-Comp compared to Zr-Hybrid due to its large microhybrid particle size. Moreover, studies have reported that nanohybrid composite resin presented smaller voids due to smaller filler particles being de-bonded from the resin while maintaining its micro-sized particles in situ, as compared to other types of composite resin material $[31,32]$. This could possibly contribute to the excellent color stability in Zr-Hybrid. Therefore, one can speculate that silica derived from rice husk allows Zr-Hybrid to minimize the absorption of coloring agents present in the infusion media. 
The passage of light through the composite resin material determines its translucency. When it comes to visible clinical changes in the translucency parameter, no thresholds have yet been established. According to the results of the present study, Zr-Hybrid was found to be more opaque than Filtek-Z350-XT and Zmack-Comp. This can be explained based on the filler size. Although composite resin with filler particle size smaller than the wavelength of visible light (0.4 to $0.7 \mu \mathrm{m})$ will appear to be transparent [6], the present finding is still considered odd as Zr-Hybrid showed the lowest translucency. The addition of zirconia could be one of the factors causing Zr-Hybrid to be more opaque than the other composite resin counterparts. Zirconia has high degree of crystalline content with great ability to scatter light, causing an opaque appearance [33]. Nevertheless, a direct comparison between zirconia filler particles in Zr-Hybrid and Filtek-Z350-XT is not feasible as the manufacturer does not disclose any information on the type of zirconia used. It could be argued that the concentration of opaque zirconia varies across different types of dental composite resins.

The refractive index also plays a major role in the translucency of composite resins as greater refractory index between filler particles and resin matrix will cause multiple reflections and refractions in the filler-matrix interface which will increase the opacity of composite resin [34]. One can postulate that the refractive index of rice husk silica is higher than that of the resin matrix causing Zr-Hybrid to exhibit greater opacity, but this hypothesis requires further investigation. This characteristic is clinically relevant especially in front teeth because the translucency of composite resin highly affects the outcome of restoration. As a result, Zr-Hybrid is more suitable to replace tooth dentine and restoring posterior teeth, where the translucency of the composite material is not a major concern. Several ways have been introduced to increase the translucency of composite material include decreasing the amount of CQ or reducing the inorganic filler content amount [35], but these may compromise the cure efficiency and color stability. Hence, a wise balance and stable color and translucency of composite resins are one of the clinical keys for a successful esthetic result [11].

One of the limitations in the present study is the assessment of optical properties of composite resins using in vitro methodological approach. It is unlikely to establish a complete exact correlation between in vitro and in vivo studies because the oral environment is difficult to be replicated in a laboratory setting. In the oral environment, bacteria, saliva, and other fluids are present which will dilute the infusion media and affect their ability to cause discoloration on composite resins. Furthermore, the drinking habits of each patient are also another factor that needs to be considered since composite resin restorations are unlikely to be subjected to infusion media for a long period. Further studies are recommended to investigate the effects of different types of opacifier, resin monomer and other types of infusion media on the optical properties of this novel nanohybrid composite resin.

\section{CONCLUSION}

Within the limitations of this study, unaged Zr-Hybrid demonstrated comparable color stability to Zmack-Comp and Filtek-Z350-XT, whereas aged Zr-Hybrid exhibited the highest degree of color stability in all four-infusion media. Although unaged and aged Zr-Hybrid showed the least translucency value compared to the commercial counterparts, no major changes were observed in Zr-Hybrid after accelerated aging in all infusion media. Soft drink caused the greatest color change while coffee had the most significant effect on translucency.

\section{Acknowledgments}

The authors would like to thank Mr Mohd Yusof Soon Abdullah during laboratory procedures and Dr Mohamad Arif Awang Nawi for statistical analysis assistance.

\section{Conflict of Interest}

The authors declared no conflict of interest.

\section{Funding}

This study was financially supported by the Universiti Sains Malaysia (USM) research university grant scheme 1001/PPSG/8012215 from the third author, USM bridging grant scheme 304/PPSG/6316456 from the second author and USM Fellowship scheme from the first author. 


\section{Regulatory Statement}

None.

\section{REFERENCES}

1. Terry DA. Direct applications of a nanocomposite resin system Part 1: the evolution of contemporary composite materials. Pract Proced Aesthet Dent. 2004;16(6):417-22. PMid:15453647.

2. Terry DA. Direct applications of a nanocomposite resin system: Part 2: procedures for anterior restorations. Pract Proced Aesthet Dent. 2004;16(9):677-84, quiz 86. PMid:15597532

3. Llena C, Fernandez S, Forner L. Color stability of nanohybrid resin-based composites, ormocers and compomers. Clin Oral Investig. 2017;21(4):1071-7. http://dx.doi.org/10.1007/s00784016-1850-z. PMid:27183827.

4. Mundim FM, Garcia LF, Pires-de-Souza FC. Effect of staining solutions and repolishing on color stability of direct composites. J Appl Oral Sci. 2010;18(3):249-54. http://dx.doi.org/10.1590/ S1678-77572010000300009. PMid:20857002

5. Topcu FT, Sahinkesen G, Yamanel K, Erdemir U, Oktay EA, Ersahan S. Influence of different drinks on the colour stability of dental resin composites. Eur J Dent. 2009;3(1):50-6. http://dx.doi. org/10.1055/s-0039-1697405. PMid:19262731

6. Awad D, Stawarczyk B, Liebermann A, Ilie N. Translucency of esthetic dental restorative CAD/CAM materials and composite resins with respect to thickness and surface roughness. J Prosthet Dent. 2015;113(6):534-40. http://dx.doi.org/10.1016/j. prosdent.2014.12.003. PMid:25749093.

7. Fontes ST, Fernandez MR, Moura CM, Meireles SS. Color stability of a nanofill composite: effect of different immersion media. J Appl Oral Sci. 2009;17(5):388-91. http://dx.doi.org/10.1590/ S1678-77572009000500007. PMid:19936513.

8. Catelan A, Briso AL, Sundfeld RH, Goiato MC, dos Santos PH. Color stability of sealed composite resin restorative materials after ultraviolet artificial aging and immersion in staining solutions. J Prosthet Dent. 2011;105(4):236-41. http://dx.doi. org/10.1016/S0022-3913(11)60038-3. PMid:21458648.

9. Arocha MA, Mayoral JR, Lefever D, Mercade M, Basilio J, Roig M. Color stability of siloranes versus methacrylate-based composites after immersion in staining solutions. Clin Ora Investig. 2013;17(6):1481-7. http://dx.doi.org/10.1007/s00784 012-0837-7. PMid:22993112.

10. Barutcigil C, Yildiz M. Intrinsic and extrinsic discoloration of dimethacrylate and silorane based composites. J Dent. 2012;40(Suppl. 1):e57-63. http://dx.doi.org/10.1016/j jdent.2011.12.017. PMid:22239912.

11. Ardu S, Rossier I, di Bella E, Krejci I, Dietschi D. Resin composite thickness' influence on $L^{*} a^{*} b^{*}$ coordinates and translucency. Clin Oral Investig. 2019;23(4):1583-6. http://dx.doi.org/10.1007/ s00784-018-2585-9. PMid:30143901

12. Acar O, Yilmaz B, Altintas SH, Chandrasekaran I, Johnston WM. Color stainability of CAD/CAM and nanocomposite resin materials. J Prosthet Dent. 2016;115(1):71-5. http://dx.doi. org/10.1016/j.prosdent.2015.06.014. PMid:26386483.

13. Kumagai S, Sasaki J. Carbon/silica composite fabricated from rice husk by means of binderless hot-pressing. Bioresour Technol. 2009;100(13):3308-15. http://dx.doi.org/10.1016/j. biortech.2009.02.001. PMid:19268582

14. Ahmed K, Nizami SS, Riza NZ. Reinforcement of natural rubber hybrid composites based on marble sludge/Silica and marble sludge/rice husk derived silica. J Adv Res. 2014;5(2):165-73. http://dx.doi.org/10.1016/j.jare.2013.01.008. PMid:25685484
15. Noushad M, Ab Rahman I, Husein A, Mohamad D. Nanohybrid dental composite using silica from biomass waste. Powder Technol. 2016;299:19-25. http://dx.doi.org/10.1016/j. powtec.2016.05.035

16. Yusoff NM, Johari Y, Ab Rahman I, Mohamad D, Khamis MF, Ariffin $Z$, et al. Physical and mechanical properties of flowable composite incorporated with nanohybrid silica synthesised from rice husk. J Mater Res Technol. 2019;8(3):2777-85. http://dx.doi. org/10.1016/j.jmrt.2019.04.014

17. Ismail NH, You LS, Abd Jalil AN, Ab Ghani NB, Awang RA. Physical and mechanical properties analyses of zirconia reinforced experimental nanohybrid dental composite (NHDC) from rice husk. Malaysian Journal of Microscopy. 2020;12(2):77-88

18. Lin GSS, Abdul Ghani NRN, Ismail NH, Singbal KP, Yusuff NMM Polymerization shrinkage and degree of conversion of new zirconia-reinforced rice husk nanohybrid composite. Eur J Dent. 2020;14(3):448-55. http://dx.doi.org/10.1055/s-0040-1713951. PMid:32599624

19. Lin GS, Ghani NR, Ismail NH, Singbal K, Murugeshappa DG Mamat N. Fracture strength of endodontically treated lateral incisors restored with new zirconia reinforced rice husk nanohybrid composite. J Clin Exp Dent. 2020;12(8):e762-70. http://dx.doi.org/10.4317/jced.56864. PMid:32913574

20. Samra AP, Pereira SK, Delgado LC, Borges CP. Color stability evaluation of aesthetic restorative materials. Braz Oral Res. 2008;22(3):205-10. http://dx.doi.org/10.1590/S180683242008000300003. PMid:18949304

21. Zhao X, Zanetti F, Wang L, Pan J, Majeed S, Malmstrom $H$, et al. Effects of different discoloration challenges and whitening treatments on dental hard tissues and composite resin restorations. J Dent. 2019;89:103182. http://dx.doi. org/10.1016/j.jdent.2019.103182. PMid:31430508.

22. Bagheri R, Burrow MF, Tyas M. Influence of food-simulating solutions and surface finish on susceptibility to staining of aesthetic restorative materials. J Dent. 2005:33(5):389-98. http://dx.doi.org/10.1016/j.jdent.2004.10.018. PMid:15833394.

23. Dede DO, Sahin O, Koroglu A, Yilmaz B. Effect of sealant agents on the color stability and surface roughness of nanohybrid composite resins. J Prosthet Dent. 2016:116(1):119-28. http:// dx.doi.org/10.1016/j.prosdent.2015.11.024. PMid:26922208.

24. Manojlovic D, Dramicanin MD, Lezaja M, Pongprueksa P, Van Meerbeek B, Miletic $V$. Effect of resin and photoinitiator on color, translucency and color stability of conventional and lowshrinkage model composites. Dent Mater. 2016;32(2):183-91. http://dx.doi.org/10.1016/j.dental.2015.11.027. PMid:26743968.

25. Schneider LF, Cavalcante LM, Silikas N, Watts DC. Degradation resistance of silorane, experimental ormocer and dimethacrylate resin-based dental composites. J Oral Sci. 2011:53(4):413-9. http://dx.doi.org/10.2334/josnusd.53.413. PMid:22167024

26. Villalta P, Lu H, Okte Z, Garcia-Godoy F, Powers JM. Effects of staining and bleaching on color change of dental composite resins. J Prosthet Dent. 2006;95(2):137-42. http://dx.doi. org/10.1016/j.prosdent.2005.11.019. PMid:16473088

27. Awliya WY, Al-Alwani DJ, Gashmer ES, Al-Mandil HB. The effect of commonly used types of coffee on surface microhardness and color stability of resin-based composite restorations. Saudi Dent J. 2010;22(4):177-81. http://dx.doi.org/10.1016/j. sdentj.2010.07.008. PMid:24109166

28. Ferracane JL. Hygroscopic and hydrolytic effects in dental polymer networks. Dent Mater. 2006;22(3):211-22. http://dx.doi. org/10.1016/j.dental.2005.05.005. PMid:16087225

29. Douglas WH, Craig RG. Resistance to extrinsic strains by hydrophobic composite resin systems. J Dent Res. 1982;61(1):413. http://dx.doi.org/10.1177/00220345820610010901. PMid:6459347 
30. Maalhagh-Fard A, Wagner WC, Pink FE, Neme AM. Evaluation of surface finish and polish of eight provisional restorative materials using acrylic bur and abrasive disk with and without pumice. Oper Dent. 2003;28(6):734-9. PMid:14653288.

31. Turssi CP, Ferracane JL, Serra MC. Abrasive wear of resin composites as related to finishing and polishing procedures. Dent Mater. 2005;21(7):641-8. http://dx.doi.org/10.1016/j. dental.2004.10.011. PMid:15978273.

32. Antonson SA, Yazici AR, Kilinc E, Antonson DE, Hardigan PC. Comparison of different finishing/polishing systems on surface roughness and gloss of resin composites. J Dent. 2011;39(Suppl. 1):e9-17. http://dx.doi.org/10.1016/j.jdent.2011.01.006. PMid:21256180
33. Baldissara P, Llukacej A, Ciocca L, Valandro FL, Scotti R. Translucency of zirconia copings made with different CAD/ CAM systems. J Prosthet Dent. 2010;104(1):6-12. http://dx.doi. org/10.1016/S0022-3913(10)60086-8. PMid:20620365

34. Tan BL, Yap AU, Ma HN, Chew J, Tan WJ. Effect of beverages on color and translucency of new tooth-colored restoratives. Oper Dent. 2015;40(2):E56-65. http://dx.doi.org/10.2341/149027-L. PMid:25275960

35. Lee YK. Influence of filler on the difference between the transmitted and reflected colors of experimental resin composites. Dent Mater. 2008;24(9):1243-7. http://dx.doi. org/10.1016/j.dental.2008.01.014. PMid:18343494.

\section{Nik Rozainah Nik Abdul Ghani}

(Corresponding address)

Universiti Sains Malaysia, School of Dental Sciences, Conservative Dentistry Unit,

Health campus, 16150, Kubang Kerian, Kelantan, Malaysia.

Email: rozainah@usm.my

Date submitted: 2021 May 20 Accept submission: 2021 July 01 